\title{
Diagnosis and Therapy of an Autistic Child
}

Adam Adamski

University of Silesia in Katowice, Faculty of Ethnology and Educational Science in Cieszyn, Poland.

*Corresponding Author: Adam Adamski, University of Silesia in Katowice, Faculty of Ethnology and Educational Science in Cieszyn, Poland.

Received date: January 21, 2021; Accepted date: April 12, 2021; Published date: April 19, 2021

Citation: A Adamski. (2021) Diagnosis and Therapy of an Autistic Child. Biomedical Research and Clinical Reviews. 3(5); DOI: 10.31579/26929406/045

Copyright: () 2021 Adam Adamski, This is an open-access article distributed under the terms of the Creative Commons Attribution License, which permits unrestricted use, distribution, and reproduction in any medium, provided the original author and source are credited.

\begin{abstract}
Knowledge of autism is growing tremendously, since the first formulation of the phenomenon of autism in 1943, there is still no cure for the cure of changes in the brain that create the symptoms of autism. I still find better ways of understanding the disease and help patients adapt, but does not give a full understanding of what autism. There are different types of therapy in the field of speech, behavior, vision, hearing, as well as drugs and dietary recommendations, but they are often ineffective. Treatments should be tailored to the individual needs of the patient.

The author of that work will pay attention to corrective therapy movement, and the mechanism of imitation, these two factors in autism do not exhibit synchronization, because the child did not received during the birth. Autistic children from the area have movement disorders, and the lack of a mechanism to follow. My research results confirm the view that the movement disorder and the mechanism of imitation are inherent in the phenomenon of autism. The study of movement disorders in children, and the mechanism of imitation, may serve as an early indicator of autism diagnosis methods. They point to the need for the development of therapies to be used from the first months of life in autism.
\end{abstract}

Keywords: autism; education; therapy; correction of movement

\section{The concept of autism and its historical aspect}

The term autism refers to the Greek word autos (alone). was first used in 1911 by the Swiss psychiatrist Eugen Bleuler. However, Bleuler did not use it to describe people who today would be called autism, but to patients with schizophrenia. Several years later, autism was given new meaning. In the 1930s, Leo Kanner, an Austrian psychiatrist, began to analyze the cases of several children at the Johns Hopkins hospital in Baltimore, Maryland.

The results of these studies were published by Kanner in 1943 in his article Autistic Disturbances of Affective Contact, in which he stated that the children he examined exhibited "extreme autistic loneliness". A year later, Hans Asperger, an Austrian pediatrician who conducted research independently of Kanner, published an article entitled Autistic Psychopathy in Childhood

He described several children in him, which, although in some ways different from Kanner's patients, seemed similarly distant to the surroundings and did not show interest in other people. Both were convinced that the children they observed suffered from a hidden disorder. They described them:

Autistic loneliness which means a tendency to focus on one stereotypical (repetitive) behavior, while completely separating from the outside world, that is people and the situation from the environment. Such isolation from the rest of the world has become the basic feature of the disorder in autism
He focuses on objects, not on people -. Autistic children ignore and avoid the company of others, including their parents. It looks as if they treat people as objects that you can either ignore or deal with without any emotional involvement.

Language problems that can take many different forms. Some autistic children acquire language skills much later than properly developing children. There are those that do not speak until the third year of life, and there are those that communicate with a language only a dozen years later. Others start talking at the right time, but then they go back in development to a speech called echolalia, which consists in repeating all or part of what the child has just heard. Many autistic children never use the pronoun "I", and when they say about themselves, they use the form "you". Instead of saying "I want a candy," she says, "You want a candy."

Difficulties in verbal communication are usually the first signal that raises suspicion of autism.

Ritual and obsessive behaviors that can take various forms. An autistic child often forces certain activities to always take place in the same way, that is, everything should happen in the same way. For example, moving from point $\mathrm{A}$ to point $\mathrm{B}$, the child insists that he always go along the path that was going this way for the first time. Even small changes in everyday routine can cause sudden anger outbursts in the child. Some children affected by this disorder also have the habit of arranging their favorite items in the same specific way. 
Extraordinary memory and other extraordinary mental skills. Although this does not apply to all children with autism, some of them are characterized by amazing memory - the ability to memorize certain things, such as poems or sports information; have the ability to memorize mathematical calculations that bordering on genius, display unprecedented musical abilities or other amazing talents. (Waclaw, Aldenrud, Ilstedt 2005).

Lack of smiling skills (in childhood and sometimes also in later life) and lack of facial expressions during the conversation. Kenner first noticed that autistic children do not smile at others and do not use facial expressions and gestures when they speak. Our observations show that some children later diagnosed as autistic did not smile at all during infancy. Sometimes this is due to facial muscle paralysis, known as Moebius syndrome.

It should be noted that both Kanner and Asperger spoke about the possibility of relationships between autism and schizophrenia, but ultimately concluded that these are two different disorders. The most important difference between them is that they appear schizophrenia even in the youngest patients - precedes at least a two-year period of normal development, and in autistic children the symptoms of the disorder are visible from the beginning of life. Therefore, it is possible to detect during the early childhood (Budzińska, Wójcik 2010.

The American Psychiatric Association in 1995 created a range of disorders of the development of autism, including them in five categories. These are:

1. Autistic Disorder - AD

2. Asperger, s Disorder - AS

3. Reett, s Disorder

4. Childchoord Desintegrative Disorder

5. Perrasive Developmental Disorder - Not Otherwise Specifical - PDD NOS.

People with autism spectrum disorders are a very diverse group in terms of social, communication and intellectual functioning. Autism can have different characters. Some autistic children do not control speech and present different levels of intellectual disability and various deficits in social development. Others may be completely communicative, may indicate attachment to people, e.g. parents, while having difficulties in establishing correct relationships with their peers and numerous stereotypes and their own behavioral patterns.

Taking a very broad look at autism, it can be said that its scope includes the following symptoms:

1. Does not participate in the play with peers

2. He likes loneliness. He is not interested in other people, he is an individualist, independent

Games. He does not need praise, he does not care for contact with others

3. He very rarely smiling

4. He interested in contact with objects than with people

5. The expression of emotions on the face is limited

6. Usually avoids eye contact with another person

7. Does not respond to your name

8. He often gets aggressive for no apparent reason
9. She uses words that are not significant for a given situation or surroundings

10. Introduces objects into uniform rotary motion

11. Rotates in one place without interruption

12. He has difficult contacts with other people, if he talks, its one topic

13. Is very sensitive to sounds and touch

14. Sometimes he does not respond to pain

15. Does not run in jumps.

16. There are no spontaneous reflexes

17. The shoulder of the imitation mechanism

18. Disturbed body movement symmetry, walking in circles, shaking his head, rocking from foot to foot, changing strange poses

19. Lack of empathy, cannot empathize with the situation of another human being

20. He easily harms others, often with great aggression and brutality, justifying that he too has been hurt. He does not see the difference that his colleague lightly hit him, and in exchange for this he shattered his head in retaliation.

21. He is very self-centered, he does only what he likes and what he is interested in,

22. He forces others to make his wishes immediately realized

23. It is difficult to correctly express speech

24. Has difficulty with tasks that require precision movements and the cooperation of both hands under the control of sight. When performing manual tasks, we can notice lips clamping or tongue extension.

25. During the conversation, he introduces digression unrelated to the topic

26. He gets angry if a pattern or sense of security is disturbed

27. Often, a child does not like hugging,rather, it strokes along itself

28. Does not understand the concept of compromise

29. They do not seek consolation from their parents if they are unhappy

30. Require constant rituals - the same plate, the same way to kindergarten, the same sequence of activities during the day - their change introduces anxiety of different intensity

31. Lack of perception of the whole and focusing attention is on details

32. They do not understand facial expressions, they cannot read basic nonverbal messages

33. He does not understand the metaphor of what the feeling of love is and what companionship is. He does not like ambiguity

34. Later in life, he thinks that parents have to give him everything, what he wants and do not interfere with his leisure activities

35. Poor motivation to work on oneself, in learning new things and establishing proper relationships

36. Has difficulty in remembering the sequences of which he is speaking, unless they are in his interests. It shows a tendency to remember using scenes and images.

He following dysfunctions occur in the Asperger Syndrome: 


\section{Distinct impairment in non-verbal behavior:}

1. Lack of looking into the eyes, does not understand the mimicry of the other person, body language - no spontaneous reflexes stereotypy of gestures Repetitive mannerist behavior and tics. Inability to develop relationships with peers appropriate to the level of development achieved

2. No need to spontaneously share joy, interests and achievements with other people (eg, not showing parents things that you are interested in)

\section{Lack of reciprocation of feelings}

\section{An extremely strong interest in one or several stereotypical themes}

\section{Strong interest in individual elements of objects}

Impaired functioning in the social and occupational sphere, etc. Sometimes there is no clinically significant delay in the development of language skills (eg, the child uses single words at the age of two years and understandable phrases at the age of three). There are no clinically significant disturbances in intellectual development. Development of skills necessary for independent functioning in adaptive behaviors. But it is noticeable: Pedantic language - Problems with waiting for your turn children but also adults with Asperger's Syndrome are very impatient people. They think that everything should happen or do it right now. (Pisula 2010).

* Breaking conversations - children interrupt the conversation, it is their natural reflex. Healthy preschool and early school children learn that when they want to say something they should signal this by raising their hands, in turn children with Asperger's Syndrome, even in junior high school or high school, do not have such a habit. Problems with voice modulation Weird prosody Inappropriate voice intonation or lack Problems with sticking to the topic and answering the question correctly * Problems with mimic and body language reading Narrow range of interests - Problems with generalizing information Problems with physical proximity. Team. Aspergers are diagnosed on average at the age of 6.5 years. (Suchowierska, Ostaszewski, 2012). (Maciarz, Drała 2000).

\section{The concept and work of imitation mechanism}

The term "Imitation" is defined as the process of learning other people's behavior and actions that results in fact that the individual who imitates these actions internalizes cultural models and social norms. This process occurs both in humans and in animals. In humans, it is called a process of socialization - children imitate gestures, words, tone of voice of their relatives. Imitation plays a versatile role in child's development: in the process of language education - speech, entertainment as well as in children social development - the child learns gender roles and moral behavior, imitates an admired person, to whom they would like to be similar (Maciuszek 1998, p.300).

These admired ones are usually parents. The child learns by trial and error, by insight, by the instruction, and for the behavior consistent with what parents expect a child receives a prize, such as recognition, approval, sympathy or love. Behavior inconsistent with the expectations of the admired ones carries a penalty - disapproval, reactions of anger, isolation from parents, physical punishment, deprivation of something, etc. (Sołowiej 1986,p. 145).

The movement is a gift that a child gets from nature. The imitation mechanism, on the other hand is given, partially given or not given at all. This mechanism cooperates with movement, and consciousness and it forms a core for the child's life. Properly developed imitation mechanism is the sign of correct psychobiological development. Such a child from their first days learns from their family and relatives feelings, movements, words and thoughts. The child responds then to changes in parents facial expression, their tone of voice and movement. The research carried out by Moore Meltzoff show that infants are able to imitate mother's movements such as the opening the mouth or showing the tongue (Ros, Marshall, Scott 2004,p. 269).

In the eighth month the child tries to attract the attention of adults by performing various movements and gestures, whereas a 10-month child imitates adult motor activities, such as moving a spoon inside a pot. A two-years old child willingly helps their mother in everyday activities by imitating her movements 3 years-old do not only mimic adult activities, but also the individual characteristics of the people such as facial expressions, gestures, movement, way of speech. Around the age of three the child imitates the attitude of parents, with whom they identify. A 1 child learning the language first mimics the sounds and intonation, then the syntax. Phonemic hearing, that is the sensitivity to human speech, is the basis of imitation of speech sounds and words.. The situation changes when the imitation mechanism is limited or when it is not given to the child at all. This lack or a limited form of the imitation mechanism causes changes in the child movement structure, in the consciousness of one's own body and the environment. The above stated facts are reflected in such disorders as autism, ADHD, dyslexia, depression, schizophrenia and anorexia. The lack of speech and imitation mechanism is the main symptom of autism (Adamski 2007,p. 131,p 160).

The child enters a babbling period in the fourth month of his life, he utters articulated sounds; like, go, da, ba ma, la, etc. At this time, the mother should enter into dialogue with the child in the form that the mother combines syllables and pronounces; baba, lala dodo, mama, dada, gogo, etc. Normal child repeats what the mother says and gives testimony that the child has an active mechanism of imitation. An autistic child will not do it. A similar thing is with the language, the mother pulls out the tongue out of the mouth and shows the child. Normal child performs this activity, an autistic child does not. An autistic child does not imitate the elderly, e.g. the mother, teacher of rhythmic, but mimics the same when it is done by the NO robot. No child imitation mechanism and motion asymmetry provides us with information that the psychologist is able to diagnose a 3 month-old child for the development of autism. In autistic therapy, the task of a psychologist, a teacher's parent, is because by his methods he has awakened this mechanism from the earliest months and years of life, because he creates a mature personality

\section{Imitation mechanism disorders}

Autism - in this disorder a child expresses the specific form of thinking, an attitude towards the environment and their own experiences. This attitude is expressed by being pulled away from reality. The patients think primarily of their own experience, including psychotic symptoms that prove deep cognitive disorder (Pecyna 2001, p. 134). An autistic child is isolated from the society, closest adults and siblings, living in their own world. Moreover, such a child is interested in insignificant objects and rejects traditional toys. The facial expression and gestures are poor. The autistic child is resistant to the attempts of imposing on them normal behavior and appropriate interpersonal contacts. Such a child does not want to take part in a team work, as well as their behaviuor is strange and routine. The low level of concentration hinders imitation that is the basis of learning process.

(http://www.aba-autyzm.org/artykuly/artykul9.doc).

Healthy children learn a variety of complex behaviour by imitation, whereas autistic children are not able to do this. Autistic child cannot join other children in a group, replicate their movements which makes the play chaotic. The lack of imitation mechanism is the main characteristic of autistic children.

http://www.ptab.univ.gda.pl/behawioralna_teoria_autyzmu.htm 
An autistic child does not imitate man's humanness, but he does very well when he performs these functions, eg a NAO robot. There is a lot of research done in this direction, which can be seen on the Internet.

\section{Education and therapy of children with autism}

Education and therapy of an autistic child, you should start by getting to know his patterns of behavior and what data the child is interested. A child with autism should provide a stable, orderly, safe environment, because it cannot function when around him too many changes. These children love to be rotated, so are recommended physical activities, rhythmic and musical. Touch with an autistic child is the primary source of knowledge. In contact use short, simple sentences, looking straight into his eyes. Autism learn to read the whole body. In education and therapy, you should use natural materials and props from his daily life, but also by presenting a multimedia exercises and tasks of the corrective movement, stimulation mechanism of imitation, which are essential in the learning process.

Education people with autism, requires consideration of learning in the field of tradi-tional methods, multimedia, based on various information technology, but also a wide therapeutic area, the aim of which is to overcome deficits and disharmony development of the student. Learning should be planned and adapted to the child who is able to understand and solve educational tasks. In the learning process should be carried out simultaneously exercises general functions: as perception, thinking, attention, intentional action, motion control, and so on. Goal can be well used in the home, as well as in recreational and playground, as well as in multimedia education ( Stefańska 2001).

Teaching traditional skills like reading, math, learning about the world or the use of the mother tongue becomes much easier and more effective if we use for this purpose the natural environment student. An important element is also autistic person learned reaction to natural stimuli and objects, as well as teaching aids that contain natural props related to his everyday life. The fundamental rule in the education of an autistic child is that the pace, form and function of exercise should be imposed by the student rather than the teacher.

The student should be active, set and control the direction of the course. The teacher in this model is a person who adapts for spontaneous interaction that is produced by the student (Bloom, Lahey 1978).

Knowledge of autism is growing tremendously, since the first formulation of the phenomenon of autism in 1943, there is still no cure for the cure of changes in the brain that create the symptoms of autism. I still find better ways of understanding the disease and help patients adapt, but does not give a full understanding of what autism. There are different types of therapy in the field of speech, behavior, vision, hearing, as well as drugs and dietary recommendations, but they are often ineffective. Treatments should be tailored to the individual needs of the patient.

The author of that work will pay attention to corrective therapy movement, and the mechanism of imitation, these two factors in autism do not exhibit synchronization, because the child did not received during the birth. Autistic children from the area have movement disorders, and the lack of a mechanism to follow. My research results confirm the view that the movement disorder and the mechanism of imitation are inherent in the phenomenon of autism. The study of movement disorders in children, and the mechanism of imitation, may serve as an early indicator of autism diagnosis methods. They point to the need for the development of therapies to be used from the first months of life in autism.

Movement disorders in children with autism have been disclosed in the lip shape, in sitting down, crawl on all fours, walking, and mobility in all motility. In normal walking, movements involving the arms and legs are symmetrical. A child with autism there is an asymmetry (Suchowierska, Ostaszewski 2012).
Movement and music are combined in a natural way and the original. Eurythmics looking for the relationship between body movement and the movement in music; the relationship of music to the movement makes a man referring to the music to know himself, his values, the complexes, acts on the system of motivation, feelings, emotions, the level of concentration and attention (Adamski 2008). (Waliczak 1997).

Physical activity in addition to the development of muscles, bones, heart and lungs, strengthen also the basal ganglia, cerebellum, and the corpus callosum, and also increases the number of connections between neurons. Movement enriches and deepens the sense of rhythm is an important equalizer efficiency of human locomotion. Calisthenics, while linking music and movement, looking for relationships between body movement and the movement of sounds ( Brink M., Smart. 1995).

The movement belongs to the natural needs of the child conditioning its proper development of biological and psychological. Dance as a form of traffic created as a natural need for movement to the music and to "manifest" their feelings through gestures, movements and facial expressions. Exercise hand-dance satisfy not only the needs of the child movement, but also develop a series of psychophysical his disposal: perception, memory, concentration of attention, responsiveness, visualmotor coordination, orientation in the scheme's own body and space. It activates the body and mind of the child, developing his imagination, provide new impressions and experiences in the field of communication and interaction in a group, developing self-discipline., Teaches conscious control over the movement of the body. Dancing is a great way to recover from stress, shock accumulated aggression and tension, as well as an excellent form of exercise, developing physical fitness (Dudkiewicz 2000).

A very important element in the development of the child's personality is fun physical - physical. The child not only practicing the movements, but to know the social world around them. Fun gives the child the fullness of life, which it needs: it is for him to work, thinking, creativity, realism, fantasy, rest, and a source of joy (Zebrowska 1973).

Particularly noteworthy therapy through the movement of Veronique Sherborn 2003. The main idea of this method is the use of movement as a tool to support the development of psychomotor and treatment of disorders of the development. This method was started in the 60 of the last century by W. Sherborne. There are several categories of Developmental Movement:

a) The movement leading to the knowledge of your own body and motor improvement,

b) Forming a compound unit movement of the physical environment,

c) The movement leading to the formation of a compound with another person,

d) The movement of the guide to co-operate in a group,

e) Creative movement (Sherborne 2003).

The method is used in educational institutions, health professionals working with children with various disorders of development, as well as in working with autistic children. During the course of children they develop a sense of security, trust in others, responsibility. Classes are designed to help your child in learning itself, in getting to trust each other, understanding others and learning to trust them, learning is an active, creative life. For children with autism who are very afraid of these contacts, it is necessary, this fear of contact with others can be eliminated by spontaneous physical play, like swinging, bouncing, rolling on the floor, playing with a doll, and then the living man.

Physical activity can be carried out with the child at home, a group in class, using the traditional method, but also by multimedia. It would create 
the appropriate agencies to develop different types of physical activity, developing physical education, and to stimulate the mechanism of imitation, Parents know their child and thus can choose the educational and therapeutic program, which will result in the process of teaching and upbringing of their child. Developing synchronization between the movement and the mechanism of imitation, activate further social, mental- processes that will enhance the educational area. This is necessary in each treatment autistic child (Adamski, Adamska 2009).

\section{Therapeutic strategies for autism}

Exercises of eye and motor coordination. Before starting the exercise, one-sided movements should be practiced, symmetrical for both sides of the body. Exercises of alternating movements. (Zabłocki 2002, p.9-21).

1. In a sitting position: a) touching alternately with the right hand the left ear and the left right hand ear; b) touching the right elbow of the left knee and the left elbow of the right knee;

c) gripping with the right hand of the left ankle and the left hand of the right ankle (also standing up); d) alternate touching the knees.

2. In the kneeling position supported straightening of the right hand and left leg and left hand and right legs.

3. Jumping from foot to foot at different speeds and in accordance with the imposed rhythm.

4. Marching combined with the swing of hands.

5. Marching with alternate swinging of arms and legs.

6. Clapping hands or winning a simple rhythm on the instrument. .

7. Standing position. Rocking to the sides.

8. Standing on one leg, then on the other with eyes open, then closed. Keeping the position as long as possible.

9. The examined kneels in front of a partner or a wall. Catching the ball thrown by the partner either reflected on the wall.

10. Walking on a rope in a straight line (the fingers of one foot touch the heel of the other feet), then backwards and sideways.

11. Marching in place, knees raised high.

12. Bouncing like a clown. At the beginning you can practice the same movements of the upper limbs, then lower ones, and then combine them.

13. Rolling on the floor in different directions (hands stacked closely along the body).

14. Playing in the "ZOO" - moving like a lizard, crocodile, walking like a duck; jumping like a hare, kangaroo etc.

15. Run or fast march with immediate stopping for a while and again go traffic.

16. Sit with your legs bent. Spinning in circles on the buttocks with and without hands help.

17. Lying in front and back. Sliding in a circle on the stomach and on the back.

18. Lying in front. Putting the box in front of you from one hand to another.

19. Lying in front. Opening the box in front of you, then moving it back to back and attempt to close behind you, rest.

20. Turning the head: left, right, up and down.

21. Running up and running down the stairs.
22 Rolling up from a grassy hill.

23. Moving through a "window" with joined hands.

24. Moving between the ladder rungs horizontally on two chairs.

25. Crossing over various obstacles (overcoming the obstacle course). Next skipping through them.

26. Playing in the "mirror" - repeating the movements of the other person.

27. Guessing activities imitated by the therapist (swimming, kicking the ball, skating).

28. Imitating gait movements of various animals - jumping frogs, elephant walking, etc.

\section{Improving small motor skills and graphomotor}

1. Crease the foam, foam balls.

2. Kneading paper, paper pulp, salt, soap, clay, plasticine.

3. Kneading small balls from newspaper paper with three fingers.

4. Crumpling paper into a ball with one hand.

5. Pulling the strings.

6. Putting toys, pasta, stick beads, string.

7. Dropping buttons into the piggy bank.

8. Folding and unfolding paper.

9. Applying successively to each other fingers of each hand: thumbthumb, pointing to pointing and so on. (Gałkowski. 1995).

10. Turning with one finger around the other.

11. Striking one hand with the forefinger into spaces between the fingers of the other hand.

12. Stroking with your fingers on the table.

13. Hanging the tissues on a string and attaching them with clasps.

14. Pushing pins into the pin board, then removing them.

15. Twisting and unscrewing caps from bottles, containers

16. Drawing chalk, coal, brush, crayons of large shapes on the board

17. Painting with adhesive paint, shaving foam.

18. Drawing a character.

19 Cutting the string and paper strips. (Bobkowicz-Lewandowska. 1995).

The study was covered 270 children from 8 months to 7 years old. The children were divided into three groups. The first group included children from 8 months to 2 years and there were 62 children, in the second group there were children after the age of two - up to 4 years and there were 84 children. The third group had children over 4 years old up to 7 years old and there were 124 children.

\section{The author conducted research in three areas.}

1. The first area covered the education of children through hypnopaedia Hipnopedia is - learning during sleep. Night "lessons" are exposed in the period from falling asleep to falling into a deep sleep and before waking up, ie in periods of "shallow" sleep. The human brain is able to receive and store verbal information at that time, which in turn can be a subject of re-learning and faster recording during the day.

2. The second area included the development of interpersonal 
communication, by building one's self in its personality structure. In a normal child up to 3 years of age in mental structures is the unity between mother and child. During this period, the child for the mother says "I". After the third year, the child distinguishes himself as "I" and mother as "You." In an autistic child this form is disturbed. He expresses himself as "You", the mother and the surroundings are a form of "You".

3. The third area that is building social relations and getting to know the environment. In this matter, one should develop the mechanism of imitation, getting to know the movement symmetry of one's own body. Teaching the ability to reproduce geometrical figures and objects, animals, etc. Teaching the perception of the whole, ignoring the focus on details.

Very important method in the treatment of autism is learning speech using hypnopaedia.

Night-time education is about reading a fairy tale while sleeping. We read two fairy tales in one session. Between one and the second fairy tale we read the content from the pictures that are on the board, that's mom, that's dad it, it's a dog, a cat, it's dad, with Adam, or Maria, etc. The next night, we read the same stories. This process is repeated for several months. With the progress of education, we change the content of science, but we maintain the continuity of content. During the day, we repeat the same action. In the child's room on the wall, or on the board, there are pictures of these fairy tales. Below these pictures there are other pictures like:

- A child with mum, a child with dad, a dog in the garden, a child in bed, the child is eating candy, cake, drinking milk, etc.

- A cat under the bed, a dog under the table, squirrels eat nuts, they jump on trees,

- The cat is playing with the ball, the dog is running,

- The child travels by train, by car, by plane

- In the garden there are chickens, ducks, birds, etc.

- The child is leading a dog

- A child on a walk,

- Fruits on the table,

- Children play football

- Children play with toys, play on various instruments musical etc.

- Children release soap bubbles

- Children sit at the table and eat fruits with their parents

- The child is washing, getting dressed, the child is holding a flower, he is wearing shoes

- The child works in the garden

- The child is painting, standing at the bus stop, running on a meadow, etc.

- Children release soap bubbles

- Children sit at the table and eat fruits with their parents

- The child is washing, getting dressed, the child is holding a flower, he is wearing shoes

- The child works in the garden

- The child is painting, standing at the bus stop, running on a meadow, etc.

During the daytime vigilance the child receives a flashlight, the second one holds a parent in his hand. The parent with his flashlight first indicates a picture from a fairy tale and tells what it is, later on other pictures, he links with a fairy tale. At first, the light from the flashlight flies over the ceiling, walls, but after a short time, the child will focus on the pictures that will inform that the child wants to satisfy his need. After a month, the movements begin to take on the logic and the child begins to combine pictures with other pictures and creates compact logical content. During this play, we imitate the child in all activities. Sometimes we help in something, but rather expect the child's activity and creativity.

We do it so that the brain is constantly stimulated by new stimuli. Brain stimulation is very important is the age between 5 and 6 years of age. During this period, the author's research shows that children usually start speech and start to speak with full sentences in which they present their mental wisdom. The pre-school period is a period in which the imitation mechanism dominates and needs to be developed

In the education of an autistic child, Shadow Theater plays a very important role. We make a screen from white canvas. We throw the light on the screen. Against the background of this light, we create different contrasts of images with our fingers, e.g. a dog's face, a flying bird, a child going, etc. We teach the child to express his states and needs on the screen with his fingers. In this way, communication is made between the child and the parent or family member. If a child wants to go for a walk, he gives information on the screen what he wants to do. The screen is available to the child at any moment.

The shadow theater is very dynamic in the development of the child's personality.

Chomsky is of the opinion that the language is a specific human biological ability that has characteristic stages of development that can be described and defined their rules and functioning parameters. Chomsky, identifies language with grammar, that is, with a system of internal rules and parameters, thanks to which language can manifest in its use. Language in the Chomsky perspective is considered to be a biological organism that has its own property, ability and rules system. It is also a specific cognitive ability that enables understanding and speaking. It is an abstract linguistic computing system that is independent of other systems with which it is or can be associated or interact with, whose initial state is common and innate for the whole species (Chomsky, Hauser, Fitch 2002).

The highest cognitive ability of a language that allows understanding the rules and parameters of functioning according to Chomski falls on the first year of life. Thanks to this ability, the child is able to recognize the rules of every language of the world until the first year, which enables him to continue his language. This phenomenon is of great importance for the development of speech in autism. In this very important period of speech development, we introduce language education through hypnopaedia.

The chomsky concept is close to the Hameroff concept. In terms of Hameroff, synapses and neurons have a complicated structure and should be considered as biocomputers (nanoprocessors). They are distinguished by the fact that they exhibit high ability to parallel calculations (parallellcomputing) in microfilaments, microtubules, along with the entire cytoskeleton. Functioning of a cell should be considered in a dynamic aspect, but not in a static one. A cytoskeleton has the ability to collectively process information in a biological cell at the molecular level and performs the function of a computer clastra. In science, many clusters were constructed to understand the functioning of the cytoskeleton, but they did not meet the expected effects (Markoff 2008), Hagan, S., Hameroff, S., \& Tuszynski, J. (2002), (Rasmussen, et al. 1990).

Research shows that artificial neural networks are not able to accurately reproduce the functions that occur in the brain. Mianowice are not able to accurately determine the hierarchy of information changing in a dynamic way, with which the brain has no problem (Hameroff 1990). 
Hameroff is of the opinion that microfilaments, microtubules, together with the entire cytoskeleton contain modules that are inherently in nature to evaluate the hierarchy of information. The multilevel neural network in the brain combines modules and has a holistic understanding of the hierarchy of information, and the highest global level of information is combined with the act of consciousness. Cytoskeletons in the cell have the ability to dynamically change intracellular organization, through changes in their network and information connections, but also to connections with neighboring cells. They also have the ability to reconfigure. The main attribute of the cytoskeleton is the plasticity of sharing your resources in a collective way, which is important in the separation and processing of information.

Processing of signals in the cytoskeleton takes place in the form that the filamentous cytoskeleton structure consists of information in strings and into data chains, in a similar way as the phonetic language is formulated. Microtubules fulfill the function of channels that carry information strings and data strings. At the same time, they protect this information against interference and crosstalk (crostok). According to Hameroff and Penrose, microtubules and the cytoskeleton perform the function of a microprocessor and should be considered as cell biocomputers (Hameroff 1998, 2007), (Penrose, Hameroff, 1995).

\section{Psychological aspect of innate mechanisms of behavior}

J. Gibson represents the direction in which he professes the principle that both animals, as and man has inherent mechanisms of behavior that were acquired in the process of phylogenesis, affecting learning and cognitive processes (Gibson 1966).

Lorenz, in his natural concept, proclaims similar assumptions and is of the opinion that just as adaptation created bodily structures for acquiring and using energy, he also created structures whose function is to obtain and use information, knowledge about the circumstances surrounding the organism and immediately take them under attention. These structures are immune to all variability and organization and are protected against any modification. Their actions are not adaptation processes, but functions of structures already adapted and ready. Lorenz is of the opinion that to explain the evident efficiency of most learning processes in the behavior of the species, the existence of innate learning mechanisms must be accepted. Inborn instructions are among the possibilities of experience and are what is given before any learning so that learning can be possible (Lorenz K., 1977, p. 45).

In these birds, when the first instinct to build the nest is awakened, they endure unlikely objects and try to fasten them to the nest by means of a pushing motion. They put them in those places that create the proper nest structure. The innate knowledge determines what object is given in a given place. The bird uses only such items that give it an appropriate and fast nest structure.

A similar thesis supported by psychological research was presented by $\mathrm{J}$. Piaget. In his

Genetic epistemology has established the existence of many a priori structures in individual development. Examining the genesis of these structures, Piaget came to the same conclusion as Lorenz. In his theory, he assumes that knowledge is an invention, a construction that arises in the mind of the individual and has a place to encode an a priori experience (Piaget J., 1969, pp. 270.77).

In the matter of speech development, Wygotski is a very interesting concept. According to his theory, knowledge is passed on to a child and transmitted through culture. A child interacting with social subjects, constructs and internalises this knowledge (Wygotski 1989, p 168).

In the matter of speech development, Wygotski is a very interesting concept. According to his theory, knowledge is passed on to a child and transmitted through culture. A child interacting with social subjects, constructs and internalises this knowledge (Wygotski 1989, p 168).

For Wygotski, the social environment is the source of models, patterns of how knowledge creation should look. The source of social knowledge, mediates in creating by the child own knowledge. Wygotski is of the opinion that learning as well as development are enforced by models and by the motivation of the child. Chomsky came to similar conclusions on the basis of language structures, stating the existence of a priori language structures, which are the basis of language functioning (Chomsky 1975 , p. 131).

The mechanism of imitation is indispensable in the ontogenetic development of a human being, and in the pre-school and adolescence period, it takes the dominant phase and has an influence on speech development. An important factor is the activation of the mechanism of imitation of sounds and mimic movements, which become the driving force of speech development. This mechanism should be awakened during a specific period of the child's life. In autism, this mechanism is less awake and fades faster than in a healthy child. Imitation is nothing more than copying a ready model or behavior pattern. The mechanism of imitation is genetically given to man, he is innate. Thanks to him, man creates unity with nature, environment and other people. Speech is a system of symbols representing phenomena surrounding us or happening in ourselves and serves to provide information about them. Human speech operates with symbols, and a symbol is a sign that does not represent only itself, but expresses something else that was assigned to it as a result of a certain contract (Zaleski 1992, p. 7).

Imitation is not exclusively human behavior, it is common and animals. We imitate above all the behaviors of people around us that allow us to gain positive reinforcement. When a small child is approached with something new and intriguing, it can be seen that it moves its body, imitating the configuration of the object. Children are great followers, aware of the movements of adults and later modeling these movements in their own way of walking, speaking, gesturing and other forms physical activity. Such imitation of the body allows them to feel and understand the world around them internally. Most social behaviors of people such as upbringing, culture, tradition, custom, fashion are based on imitation. It is not the case that the decision on who becomes our model depends entirely on individual preferences or personal characteristics. It is also influenced by cultural interactions that shape individuals in such a way as to enable them to function socially in this culture (Domachowski 2000 p.78).

Research conducted by Henryk Schaffer (1994, p.72) showed that some of them the parameters of our sense organs contribute to the fact that the human infant chooses those cultural interactions that are directed at other people. And so the hearing is the most sensitive in this frequency area, which is characteristic of the human voice. The result is that such sounds are easier to capture by the infant. Another example is the warmth of the human body. The child is more likely to cling to the mother's body than to the body of any other animal species. Among the tactile sensations, they attract the attention of the infant, mainly those that reflect the texture of human skin. The same applies to the smell preferences. For an infant during the first year of life, the mimic, pantomimic and vocal reactions that the child currently perceives in his surroundings are imitated. When learning a language, a small child imitates sounds and notation first and then syntax. (Szychowiak 1982, p. 29).

Starting from the thirteenth and fourteenth months of life, we observe a new form of imitation in the child's behavior. This is so-called deferred imitation based on the reproduction of the behavior of a person absent at a given moment. The form of postponed imitation is also the performance of activities outside its proper context: this is the case, for example, when 
a child pretends to be asleep. Postponed imitation is the beginning of socalled play in pretend, which will develop over the next few years, being a source of many experiences and joyful experiences. It requires a higher organization of mental structures than direct imitation. Thus, a child in the age of early childhood reproduces not only what it currently sees and what intrigues it, but also what it has observed earlier and what has been coded in its memory. Most often these are behaviors that are intended to make the child look like parents (Szychowiak 1982, p. 31).

In the pre-school period, we are talking about identifying with people around you. Identification in a child is the first form of attachment to a parent. It is also the embodiment of his role and the attribution of his power. It is one of the most important mechanisms of education of personality and upbringing. In the pre-school period, children identify with their mother, in the later period fathers take over this role, especially with regard to boys. So the boys have to go through the identification process with their mother before they can identify with their fathers. The girls, however, remain with the same identification model from the beginning to the end of their development (Rembowski 1978, p.132).

Imitation as a developmental mechanism is undergoing evolution. First, the child imitates facial movements, then hand movements, and finally movements of the whole body. An important development stage is imitation of manipulating the subject, which we observe at the end of the infancy age. It requires from the child not only the skills of observation and the appropriate level of development of hand movements, but also the ability to understand the situation and predict the effects of activities (Harwas-Napierała, Trempała 2001, p. 137).

In his practice, Lovaas adhered to the principle that the basic task is to develop appropriate habits in the child through imitation. The most important and primary element is the induction of phonation, starting from the articulation of sounds, isolation, then by attempting to combine them, producing the first syllables and words in the process of imitation, which leads to the utterance of the full word and later the sentence. Launching the phonation is tantamount to starting the innate speech mechanism programmed in the biological system (Lovaas 1993, p.31).

Delacato in his research showed a strong connection between speech and sensory perception. The researcher distinguished two determinants of human development: stage, which is synonymous with panta rhei Heraklita, and the stimulativeness of brain processes. Lack of activation of cognitive processes, mental functions at a given stage of time (developmental period) leads to pathology. (Delacato 1995, p.85, 100).

Fridlung A.J. on the basis of the conducted research, he noticed that in the brain there are innate structures in the form of matrices containing characteristic features of facial expressions and the tone of the voice, used to recognize basic emotions. This means, in essence, that regardless of cultural conditions, as a species we have been equipped with the basic abilities to identify important stimuli from an adaptive point of view (Fridlund 1994).

Speech sets very high demands on breathing muscles, the muscles of the larynx, throat and oral cavity. First of all, it is about the speed of movements, their precision and rhythm. Tissue tissue is a piezoelectric, so the vibrations of the air during breathing and speaking are locally transformed into an oscillation of the electric field that coordinates these processes and is responsible for their proper course. Low motor efficiency of the articulatory organs causes that the child cannot perform precise, subtle movements needed to articulate a given voice, even when there are no deviations in their anatomical structure. Children with severely impaired motor skills, static and dynamic coordination of the whole body learn to speak later and often have speech disorders. Healthy childbirth, demonstrates many innate reflexes, important for the development of his speech. These are reflexes from the area of the mouth: reflex swallowing, sucking, pulling out the tongue, biting and chewing. Without these reflexes, speech would develop in a very delayed manner. Another example confirming the existence of innate mechanisms of behavior may be that children from around the world raise their hands when they want to be taken by an adult. The inherent mechanism of behavior is also the temperament of a man who determines body movements, strength of voice, changes in ways of behaving, etc. (Bogusławska-Wilczyńska, Stopa, Kurywczak, 2000, p. 32).

The act of speaking is very difficult, much more difficult than understanding speech. Verbal expression is associated with precise movements of respiratory and articulatory muscles. It takes about 50 billion seconds to pronounce a vowel. and consonants about 10 for a few seconds. These are very short periods and the movements of the vocal apparatus must be very fast and precise. The transition from one voice to the next is associated with a large change in the position of the muscles. The precision of these movements must be very accurate, otherwise the spoken voice will have an abnormal acoustic structure and understanding it will be difficult or even impossible. It should be concluded that this is a congenital activity and that this mechanism is guided by the bioelectronic process, which mobilizes the vocal apparatus to activate vocal phonation and to utter a specific sound, syllable or word. Learning a language requires the child to understand the difference in roles between the speaker and the listener, as well as the specific communication intent of an adult in the context of a given situation. It should be concluded that without a congenital mechanism of behavior, the child would learn speech for several years (Chomsky 1980).

From the point of view of bioelectronics, electric field resulting from the movement of muscles as biological piezoelectrics plays an important role in speech, but also as a result of stretching, compression, protein structures such as elastin, keratin, collagen, actin, myosin etc. These structures are a biological piezoelectric and vibrations air during breathing and speaking are locally transformed into an oscillation of the electric field that directs the entire speech mechanism. It is an innate disposition for action, creation of cognitive processes and mental functions.

Biological piezoelectrics and pyroelectrics are able to transform mechanical and thermal energy into electrical energy, whereby an electric field is triggered which changes the energy state of neighboring cells. This field records the perceptual impression not only in the brain, but also in the whole organism, i.e. everywhere where there is protein, DNA, RNA. Biological system from the point of bioelectronics, it can be said that it creates a set of nanocomputers. Biological computers (a nerve cell creates a brain structure), form an internet network, where the central place of management is the brain. These programs are responsible for the human nature and its psychophysical development. They have patterns that nature is innate. They also have the ability to imprint a sensual stimulus into an empty pattern space.

In this approach, the process of life finds a justification in Angyal's approach to the whole as a primary unity in the multiplicity and diversity of parts (Angyal, 1941, p.100).

What is the use of this in the mental development of a child? It turns out that this is the initial process. In the infant, perception is made as a whole, for example in a room. A child perceiving peace does not notice the chairs, the table, etc. separately, but sees everything as an inseparable whole. This is a different process than an adult who notices figures appearing against something. Behind every experience there is a real dynamic impact of the environment on the child's body. The essence of any environmental impact is the reconstruction in the sphere of internal experiences. The reconstruction is connected with the change of attitudes determining the child's relation to the environment, and at the same time it is the transformation of the original whole in favor of distinguishing the 
structural parts of the whole, recognizing them, differentiation and organization. (Zohar, Marshall 2001, p. 204).

Despite the huge neuropsychological knowledge, today we know little about the formation of thought and somatisation. People often do not know their body or some of its parts. This is because the cognitive process of your body has not been adequately imprinted in your psyche, or because of the negating of the body spheres with negative emotions that the subject tries to avoid naturally. The dramatizing experiences of man so condition that he cuts himself off and, as a result, he does not receive any sense signals from a given area of the body. Thanks to working on the body schema and getting in touch with our own inner space, we reach the inner world that is our property. This is the first step in the process of therapy of physical deadlock points, i.e. release of accumulated tensions. You need to start with approximating the scheme of your own body with the possibility of accepting different parts of it, experiencing pleasant sensations, feeling satisfaction and detente (Cavalher 2001, p.70)

Normally the fetus learns rhythm and vibrations by listening to the mother's heartbeat and breathing, as well as constant electrical impulses and electromagnetic fields created by the biological system (Hannaford 1998, p.148).

Frequent exposure of the mother to the influence of external electromagnetic fields can disrupt these maternal rhythms and negatively affect the child's rhythmic learning. Children born without a sense of inner rhythm can not be pacified by swaying, humming or allowing him to suck. It only makes them irritable (Coulter 1993, p. 127).

The body plays an integral role in all intellectual activity from fetal to old age. The movement activates nerve connections throughout the body, creating a learning instrument from the whole body. The movement integrates and anchors new information and experiences in our neural networks. It is necessary for all actions by which we express and define our learning, our reasoning and ourselves. Movement improves learning effectiveness An example of this can be educational kinesiology exercises from the Denison canon, which are also referred to as brain gymnastics.

Similar results were obtained by autistic children who learned to interact quickly with other people first by associating gestures, feelings and then words.

Inherent mechanisms of behavior are the administrator of programs and are responsible for the scope of functions and the launch of program files assigned to the given organ. This is done by loading the stimulus into a pattern that leads to the awakening of a specific psychic function, for example speech, feelings or attention. Human psychological development in ontogenesis is phased. Each phase must adopt a specific structure so that the next one can start. Adolescent learning mechanisms and the mechanism of imitation help to grow up in the start-up of a specific phase. The lack of arousal of innate learning mechanisms, as well as the poor transformation from the visual world into the world of touch leads to dyslexia. An example is the lack of crawling that leads to dyslexia.

Innate instructions are basic knowledge for human development and must exist for learning to develop and achieve a specific effect (Lorenz 1977, p. 126.

To this end, we educate an autistic child from the earliest months of life.

Education should be comprehensive in order to stimulate the senses to their perceptual activities. We are able to diagnose autistic children as early as 5 months of age through the activity of the imitation mechanism. If he does not have his severity, then such a child was born with the features of autism. The earliest therapy begins with the fact that we put the headphones on the child's ears and through it we pass on the mother's voice, mother's heart work, mother's singing. During the day we do it in several sessions of 30 minutes.

- We run various games with the child

- Theater values should be a basic education, because chromo therapy is the most effective therapy with autistic children. On the screen, the child can express their needs, e.g. going to the park that is hungry, wants to play and have fun etc. We build interpersonal communication.

- We teach a child to swim, jump, dance, ride a scooter, ski, bike, catch the ball,

- We teach how to play instruments, sense of rhythm, drawing, painting,

- playing with the microphone, singing, imitating the sounds of birds, various domestic animals, orforest, splashing in the water, we create sounds from the water. We repeat the child's interests,

- playing and imitating the NAO robot. Children like playing with the NAO robot.

Everything is done so that the brain is constantly stimulated to various life activities.

\section{References}

1. Adamski A. Rola procesów bioelektronicznych w kształtowaniu percepcji zmysłowej ifunkcji psychicznych człowieka. Wyd. Uniwersytet Śląski. Katowice - 2006.

2. Adamski A. Psychologiczny wymiar czasu i przestrzeni w ontogenezie człowieka. Wyd. Compal Bielsko- Biała - 2007 r. s. 176.

3. Adamski, A., 2008: The perception of music, its dimension in art and psychology quantum. Ed. Compal. Bielsko-Biala. 2008. p.163. ISBN 978-83-926186-4-5.

4. Adamski A., Adamska A. Wychowanie dzieci i młodzieży przez muzykę i dla muzyki.Praca zbiorowa pod red: D. Kadłubiec i A. Adamski W: Muzyka, światło, ruchw rozwoju osobowości człowieka. Wyd. Compal. Bielsko- Biała 2009r, s. 124 - 135.

5. Adamski A. Ruch w edukacji i wychowaniu dziecka przedszkolnego. Studia z Teorii Wychowania. T.III: ,2, z. 5, s,92113. 2012

6. Adamski A., Adamska A. Education of children with autism in elearning.Tytuł książki.: E-lerning and Intercultural Competences Development in Defferent Countries. Redaktor : Eugenia Smyrnowa - Trybulska. Katowice. Wydawnictwo: Studio NOAN. 2014.

7. Angyal A., 1941: Foundation for a science of personality. New York. The Viking Press

8. Bloom, L., Lahey, M., 1978: Language development and language disorders. New York,Wiley.

9. Brink, S., Smart, M., New research suggests, That folks from 8 to 80 can shape up Their brains with Aerobic exercise, [in]: US World and News Report 118 (19) 1995.p. 79.

10. Bloom L, M. Lahey M.1978. Language development and language disorders. New York, Wiley1978.

11. Błeszyński J. 1998 . Mowa i język dzieci z autyzmem. Słupsk. Wyższa Szkoła Pedag.w Słupsku.

12. Bobkowicz-Lewandowska.L Autyzm dziecięcy zagadnienia diagnozy i terapii"Gdańsk 1995.

13. Budzińska A. Wójcik M. Zespół Aspergera. Wydawnictwo Harmonia. Gdańsk 2010.

14. Bogusławska A., Stopa A., Kurywczak K. , 2000 : Interdyscyplinarna ocena opóżnionego rozwoju mowy. „Nowa Medycyna", T.7, z, 99, t. 7, s. 47- 58.

15. Brauner. -A..F „Dziecko zagubione w rzeczywistości.” Konferencja Naukowa Gdańsk 1997. 
16. Cavalher, F., 2001 . Wizualizacja. Przeł. A. Suchańska . Poznań: Dom Wydawniczy Rebis.

17. Coulter D.J. 1986; Children at risk: The development of dropquts.Longmont,CO: Coulter Public Sound Cassette.

18. Delacato C.H. 1995. Dziwne, niepojęte. Dziecko autystyczne. Warszawa.

19. Dutkiewicz, K. 2000: Body language through dance. Life of the school in 2000, 6.p. 67-78

20. Chomsky N. 1975; Questions de semantique. Paris: Edition du Seuil.

21. Chomsky N.1980: Excerpted in the behavioral and brain. Scienences", No 3, s.1- 61.

22. Chomsky, N. 1968. Language and Mind. New York: Harcourt Brace Jovanovich.

23. Chomsky, N., Hauser, M., Fitch T.W: 2002. The Faculty of Language: What Is It, Who Has It, and How Did It Evolve?, "Science" vol. 298.

24. Chomsky, N. 2002. On Nature and Language. Cambridge: Cambridge University Press.

25. Fridlund A.J., 1994: Human facial expression.San Diego: Academic Press, Incorporation.

26. Gałkowski. -T „Dziecko autystyczne w środowisku rodzinnym i szkolnym".Warszawa 1995

27. Grandin T., Panek R.: Mózg autystyczny. Podróż w głąb niezwykłych umysłów, Copernicus, Center Press Sp. Z o.o., Kraków 2016.

28. Gibson J. J. 1966. The senses considered as perceptual system. Boston: Houghton Mifflin.

29. Gibson J.J.1972. The affordances of the environment. Unpublished Manuscript. Perceptin 6,

30. Hameroff S.R. Watt R.C. 1982. Information processing in micotubules. Journal Theoretic, Biolog. 98. 549- 561.

31. Hameroff 1990. Computational connectionism within neurons: A model of cytoskeletal.

32. Hameroff S.R. 1994. Quantum consciousness in microtubules: An intraneuronal substrate for emergent consciousness? J.of Consciousness Stud.1:91-118.

33. HAMEROFF, S.R. 1998: Quantum Computation in Brain Microtubules. The Penrose -Hameroff Orcho Orch OR model consciousness. Philosophical Transactions of the Royal Society 356: 1869-1896.

34. Hannaford C. , 1998 : Zmyślne ruchy, które doskonalą umysł. Przeł. M. Szpala,Warszawa : Oficyna Wydawnicza Medyk.

35. Harwas - Napierała B., Trempała J. , 2001 : Psychologia rozwojowa człowieka. Warszawa.: PWN.

36. Lorenz K ., 1975 : Tak zwane zło. Przeł. P. Kuliga. Warszawa : PIW.

37. Lorenz K .,1977: Odwrotna strona zwierciadła. Przeł. K.Wolicki. Warszawa : P.I W.

38. Lovaas O.I.L. 1993. Nauczanie dzieci niepełnosprawnych umysłowo. Warszawa.

39. Lisiecka M,.Sarnowska.J. Hipoterapia” w „Edukacja osób autystycznych" Gdańsk 1997.

40. Markoff, J.: Herculean Device for Molecular Mysteries (ang.). The New York 2008.

41. Maciarz A. Drała D. Dziecko autystyczne z zespołem Aspergera. Kraków 2000.

42. Maciuszek J. Naśladownictwo i konformizm [w:] Szewczuk W. (red.): Encyklopedia psychologii, Wyd. Fundacja Innowacja, Warszawa 1998, s. 300.

43. Obuchowska I.: Psychologia kliniczna dzieci i młodzieży wybrane zagadnienia [w:] Sęk H. (red.): Psychologia kliniczna, t.2, W-wa 2005, wyd. PWN, s. 41.
44. Pecyna M. Psychologia kliniczna w praktyce pedagogicznej. Wyd. Żak, Warszawa 2001.

45. Penrose R. , 1995: Nowy umysł cesarza. O komputerach, umyśle i prawach fizyki. Przeł.P. Amterdamski . Warszawa: PWN.

46. Penrose R., Hameroff S.R., 1995: Quantum computing in microtubules: Selfcollapse as, a possible mechanism for consciousness: Toward a science of consciousness.

47. Hammeroff S.R., Kaszniak A.W., Scott A.C. (eds.): Cambridge: MIT Press Mass, s.34- 43.

48. Piaget J., 1969: The Mechanisms of perception. New York: Basic Books.

49. Piaget J., 1983: Piaget,s theory.In: .Mussen P.H., (ed.). Handbook of child psychology T.I, s. 56-67.

50. Pisula E. Małe dziecko z autyzmem . Gdańskie Wydawnictwo Psychologiczne. Sopot 2010.

51. Przetacznik -Gierowska >, Makiełko G.1985. Psychologia rozwojowa i wychowawcza wieku dziecięcego. Warszawa . Wydaw. Szkolne i Pedag.

52. Ross V., Marshall H., Scott M.: Psychologia dziecka, Wyd."WSiP”, Warszawa 2004, s.269.

53. Schaffer H. , 1994 : Początki uspołeczniania dziecka. Warszawa: PWN.

54. Schiefelbein S. 1986: Beginning the journal. Washington:" National Geographic Society, No 7, s 28-49.

55. Sherborne V. Developmental movement for children. Cambridge University Press 1990.

56. Sherborne, W., growing movement for children. The backdrop. with j, ang. M. Bogdanovich. PWN. Warsaw 2003.

57. Siemińska A., Internet in the preparation of teachers for the application of information technology, Adam Marszalek, Torun 2007, p.17. ISBN 978-83-7587-268-2.

58. Stefańska, R., Autism and education. World Autism No. 3, Fall 2001, p. 34.

59. Suchowierska, M., Ostaszewski, P., bubble, P., 2012: The Behavioural therapy of children with autism. Ed. GWP. Warsaw 2012. EN ISSN 2083-4179.

60. Sołowiej J. Identyfikacja dziecka z rodzicami [w:] Ziemska M. (red.): Rodzina i dziecko, Wyd. PWN, Warszawa 1986, p. 144145.

61. Teitelbaum O, Teitelbaum Ph:. Does your baby have autism? Detecting the earliest sibnes of autism. New York. Copyright 2008.

62. Waclaw W., Aldenrud U, Ilstedt 2005. Dzieci z autyzmem izespołem Aspergera. Katowice.

63. Waliczak G. „Muzykoterapia jako jedna z form edukacji dzieci autystycznych”. w „Edukacjaosób autystycznych” Gdańsk 1997.

64. Wolski A. 1996. Terapia i wspomaganie psychoruchowego rozwoju dziecka z cechami autyzmu. W: W.i J.Pileccy /red./: Stymulacja psychoruchowego rozwoju dzieci obniżonej sprawności umysłowej. Wyd. Naukowe WSP, Kraków. 1996. ISBN, 978- 81-9161-8-5.

65. Wygotski L, 1984: Psychologia sztuki. Warszawa. PWN.

66. Wygotski L., 1989: Myślenie i mowa. Warszawa : PWN.

67. Wygotski L. 2002: Wybrane prace psychologiczne - dzieciństwo i dorastanie. Poznań Wyd.: Zysk.

68. Zabłocki K.J.. „Autyzm.” Płock 2002, p.9-21.

69. Zohar D., Marshall J. .N. , 1994 : The Quantum Society, Bloomsbury. New York : London and William Morrow.

70. Zohar D., Marshall I.N., 2001: Inteligencja duchowa. Przeł P. Turski Poznań :Rebis.

71. Zalewski G. 1990 . Konstruktywne i destruktywne stany świadomości. Zmatematyzowany model świadomości i samoświadomości. Przegląd psychologiczny 33, 507-519. 
72. Zalewski G. 1992. Psychologiczne modele świadomości i samoświadomości. Dział Wydawnictw Filli U.W. Białystok.
73. Żebrowska, M. Psychology of children and adolescents. PWN. Warsaw 1973. 